Copyright (C) University of Washington. Published by Cambridge University Press, 2021. This is an Open Access article, distributed under the terms of the Creative Commons Attribution licence (http://creativecommons.org/licenses/by/4.0/), which permits unrestricted re-use, distribution, and reproduction in any medium, provided the original work is properly cited.

\title{
Eolian sedimentation in central European Auel dry maar from 60 to $13 \mathrm{ka}$
}

\author{
Florian Fuhrmann* (D), Klemens Seelos, Frank Sirocko \\ Department for Geoscience, Johannes Gutenberg-Universität, Johann-Joachim-Becher Weg 21, Mainz, 55099, Germany \\ *Corresponding author at: Department for Geoscience, Johannes Gutenberg-Universität, Johann-Joachim-Becher Weg 21, Mainz, 55099, Germany. \\ E-mail address: flfuhrma@uni-mainz.de (F. Fuhrmann).
}

(Received June 4, 2020; AcCePTED October 8, 2020)

\begin{abstract}
The climate in central Europe during the last $60 \mathrm{ka}$ is characterized by rapid temperature and moisture changes and strong cold periods (Heinrich events). All these variations are preserved in sediments of marine and also some terrestrial archives. Here we present a continuous, terrestrial sediment record with almost all Greenland stadials and Heinrich events between 60 and 13 ka visible from carbonate roundness of the Eifel Laminated Sediment Archive Dust Stack-20 and $\mathrm{CaCO}_{3}$ data for central Europe. The carbonate roundness data show almost all stadials between 60 and $13 \mathrm{ka} . \mathrm{CaCO}_{3}$ data show a general transport system change with the beginning of Heinrich event 3 . Since there are no carbonates west of the Auel Maar, we conclude that the eolian-transported grains were not transported by westerly but easterly winds. These postulated easterly winds during the last glacial maximum are supported by similar findings of previous works.
\end{abstract}

Keywords: Paleoclimate; Eolian Dust; Central Europe; Last glacial period; Last glacial maximum; Easterly winds

\section{INTRODUCTION AND SITE DESCRIPTION}

The Eifel region in central Europe is an established geoarchive for climate reconstruction in central Europe as the climate in the area between Belgium and Poland is thought to have been nearly homogenous on longer time scales (Wernli and Pfahl, 2009). Here we present a new eolian dust record from the Auel dry maar, located in the Eifel volcanic field in Germany (Fig. 1). The record spans almost the past 60 $\mathrm{ka}$, as the volcano erupted around $59.3 \mathrm{ka}$ ago (Sirocko, unpublished data). The Eifel volcanic field consists of seven recent maar lakes and about 60 dry maar lakes (sediment-infilled former maar lakes). The silted-up Auel Maar lake had a diameter of about $1.3 \mathrm{~km}$ and a depth of $105 \mathrm{~m}$ (Brunck et al., 2016; Sirocko et al., 2016). A small, 5-km-long creek (modern "Tieferbach") filled up the maar lake until the early Holocene (Brunck et al., 2016). Hence, we have chosen to end the presented timeseries with the Laacher See Tephra, which marks the date of 12,930 yr b2k (all ages are given in b2k, years before 2000 Common Era)

Cite this article: Fuhrmann, F., Seelos, K., Sirocko, F. 2021. Eolian sedimentation in central European Auel dry maar from 60 to $13 \mathrm{ka}$. Quaternary Research 101, 4-12. https://doi.org/10.1017/qua.2020.81 and is established from varve counting (Brauer et al., 1999). The creek fed the maar lake, which led to a comparatively high sedimentation rate of about $2 \mathrm{~mm}$ per yr (Sirocko et al., 2016). The geology surrounding the Auel dry maar belongs to the Variscan basement terrain of the Rhenish Shield. It is characterized by non-calcareous sand-, silt-, and mudstones mostly of Lower Devonian age. Carbonate rocks are not found west of the dry maar in the catchment area of the creek (see Fig. 1), but are exposed to the north, east, south, and southwest in the immediate vicinity of the Auel dry maar (Meyer, 2013; Landesamt für Geologie und Bergbau, 2020).

The climate of central Europe was characterized by the Weichselian ice age during the last $60 \mathrm{ka}$. The Early Marine Isotope Stage 3 (MIS3; Lisiecki and Raymo, 2005), beginning around $60 \mathrm{ka}$ and lasting until $48 \mathrm{ka}$, was warm and humid with intensified tree growth (Sirocko et al., 2016). Speleothem growth is documented in the Bunker Cave in close proximity to the Eifel (Weber et al., 2018). The middle MIS3 (48-38.5 ka) was characterized by colder and drier conditions (Sirocko et al., 2016) and increased dust transport processes (Seelos et al., 2009). These conditions intensified within the late MIS3 (38.5 to $24 \mathrm{ka}$ ), and dust became the major component of Eifel maar lakes (Sirocko et al., 2013). 


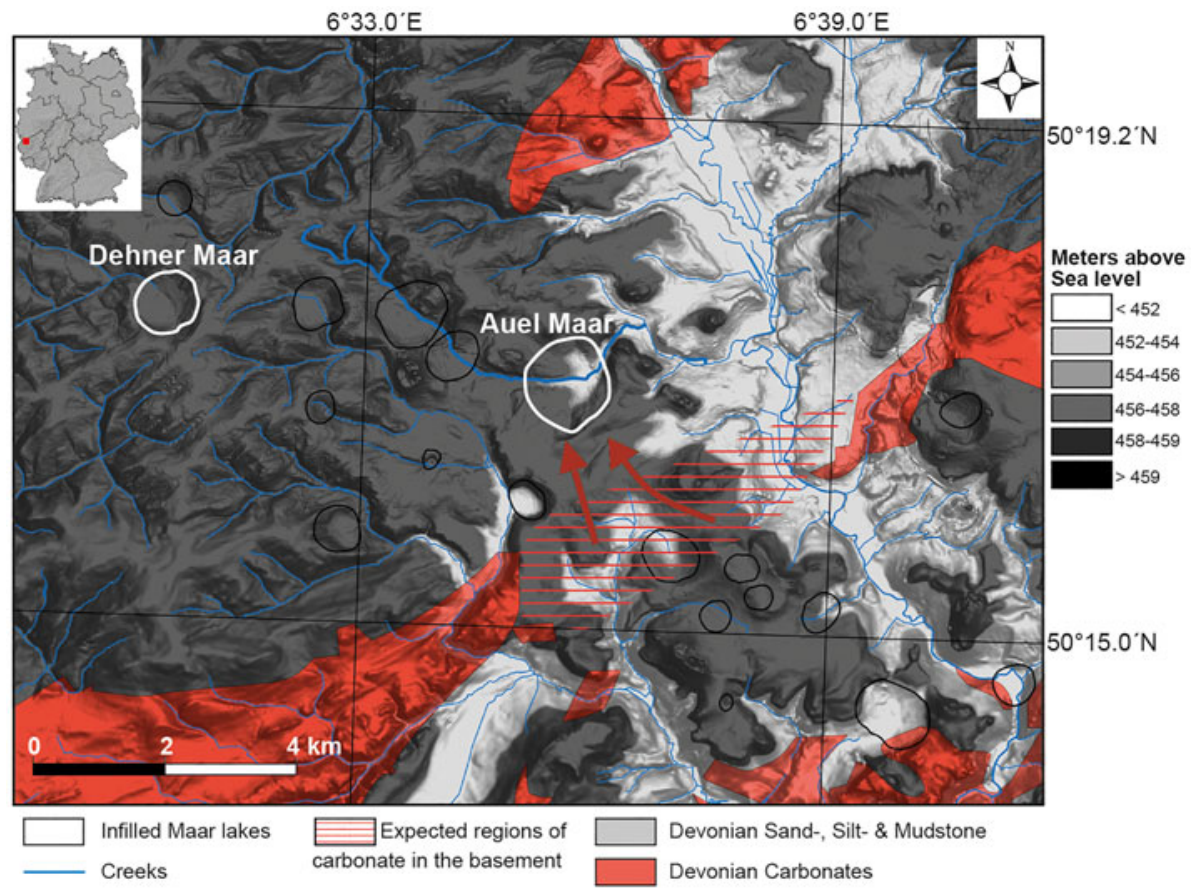

Figure 1. (color online) Simplified geological map of the Auel dry maar area showing basement rocks and calcareous rocks of the Eifel (modified after Meyer, 2013; Landesamt für Geologie und Bergbau, 2020).

During the last glacial maximum (LGM, 26.5-19 ka; Clark et al., 2009), dryness and cold and westerly to northwesterly winds were predominant (Hatté et al., 1998; Huijzer and Vandenberghe, 1998; Renssen et al., 2007), but a number of easterly wind events were still apparent (Dietrich and Seelos, 2010). High wind speeds and increased aridity are usually accompanied by intensive dust and loess deposition (e.g., Sun et al., 2010). After the LGM with maximum ice sheet extent, the glacial termination took place, which was characterized by increased moisture and temperature (e.g., Clark et al., 2009; Denton et al., 2010). However, for the larger region around the Eifel, which includes Belgium (e.g., Vandenberghe et al., 1998; Rommens et al., 2007; Haesaerts et al., 2009, 2016), northern France (e.g., Antoine et al., 2003), and the Rhine valley (e.g., Antoine et al., 2001; Rousseau et al., 2007; Frechen et al., 2010; Frechen and Schirmer, 2011; Krauß et al., 2018), and also for China (e.g., Lu et al., 2004; Sun et al., 2010), evidence of intensive loess deposits during the glacial termination and the Holocene is presented.

Eolian particles of grain sizes larger than $63 \mu \mathrm{m}$ are often transported locally or regionally in saltation. However, grains of this size are lightweight enough to be transported by wind, and they represent more local or regional dust compared to the silt fraction (Vandenberghe, 2013). During this transport process, edges and corners are cut off and grains become rounder. Percussion marks can also be found after such a transport. Therefore, more-rounded grains of this size are a clear indication of eolian transport (e.g., Krinsley and Doornkamp, 2011; Mycielska-Dowgiało and Ludwikowska-Kedzia, 2011; Vandenberghe, 2013; Woronko and Pisarska-Jamroży, 2016).
Previous studies have shown increased dust activity during glacial and stadial times for several regions in Europe. For example, the Nussloch loess sequence (e.g., Rousseau et al., 2007; Antoine et al., 2009) revealed detailed climate variations comparable to the Greenland Interstadials (GI) recorded in the Greenland ice cores (e.g., North Greenland Ice Core Project Members et al., 2004; Rasmussen et al., 2014). The landforms and grain characteristics of loess and eolian sand have traditionally been used as a basis for dust reconstruction in west and central Europe (e.g., Manikowska, 1985; Gozdzik, 1991, in Poland; Vandenberghe, 1991; van Huissteden et al., 2001a, b; Kasse, 2002, in the Netherlands). In contrast to the mentioned loess sequences, the Eifel Laminated Sediment Archive (ELSA; Seelos et al., 2009; Sirocko et al., 2016) Dust Stack-20 of the Auel dry maar represents a continuous sedimentation within a terrestrial archive with a high temporal resolution that extends from a millennial time scale to a finer scale of annual total organic carbon data (Sirocko, unpublished data). Other established dust records include, for example, the loess plateau in East Asia (e.g., Sun et al., 2010) or marine sediment cores of the Arabian Sea (e.g., Schulz, et al., 1998; Deplazes et al., 2013). Eolian dust reconstructions are also known from the Atlantic Ocean, especially from the Sahara Desert (e.g., Collins et al., 2013). A kind of reference record for eolian particle transportation in the Northern Hemisphere is represented by the dust reconstructions of Ruth and colleagues (2007) from the North Greenland Ice Core Project (NGRIP) ice core. They investigated the dust concentration and reconstructed a long and continuous eolian time series. 
As yet, there is not a commonly accepted definition for "loess." Nevertheless, there is a fundamental consensus that loess is a mainly silt-dominated eolian dust deposit (Sprafke and Obreht, 2016) often enriched in carbonates. Hence, we interpret the dust sequences of the Auel Maar as a lacustro-eolian deposit comparable to loess as defined by Vandenberghe (2013). The key objective of this paper is to present a dust record, reconstructed from carbonate roundness and $\mathrm{CaCO}_{3}$ data of the ELSA Dust Stack-20, that will serve as a continuous terrestrial sediment record for central Europe with almost all Greenland stadials (GS) and Heinrich events between 60 and 13 ka represented.

\section{METHODS}

The ELSA Dust Stack-20 was composed of two overlapping sediment cores (AU3 and AU4) from the Auel dry maar. The approximately 100-m-long cores (see Supplementary Material) were synchronized using different marker layers (such as tephrene [Förster et al., 2020], prominent diatom layers, distinct $\mathrm{C}_{\text {org }}$ maxima, etc.) and then divided into 1000 samples of $10 \mathrm{~cm}$ each (Sirocko et al., unpublished data). Each of these samples covers about 50 years, and the average sedimentation rate is $1.7-2 \mathrm{~mm}$ per yr (Sirocko et al., 2016, unpublished data). Events such as landslides, tephrenes, or large flood layers were subsequently removed from the stack to achieve temporally continuous data series. The $10-\mathrm{cm}$ samples from the Auel cores were used for several measurements, including loss on ignition (LOI), $\mathrm{CaCO}_{3}$ and grain measurements (this study); beetle remains (Britzius et al., unpublished data); macro remains and pollen (Sirocko et al., 2016); and flood layers (Brunck et al., 2016). For core photos, see the Supplementary Materials. For further methods, $\mathrm{C}_{\text {org }}$ (chlorins) data, and the respective age model, see Sirocko and colleagues (unpublished data).

The stratigraphy of the core is based on tephra layer correlation and palynostratigraphy, but mainly on ${ }^{14} \mathrm{C}$ dating and the ${ }^{10} \mathrm{Be}$ maximum during the Laschamp (Sirocko et al., unpublished data). The core was then fine-tuned using the LOI and $\mathrm{C}_{\text {org }}$ (chlorins) (organic carbon) of the ELSA-20 Auel Stack and a Bayesian Age Model in comparison to the $\delta^{18} \mathrm{O}$ of the NGRIP ice core (see Sirocko et al., unpublished data).

The $\mathrm{CaCO}_{3}$, LOI and grain analyses were performed from the 10-cm bulk stack-samples. The LOI was analyzed with a Muffle furnace B410 (Nabertherm, Lilienthal). Therefore, 4 grams of dry sample material were mortarized and homogenized. The samples were then placed in the muffle furnace af $550{ }^{\circ} \mathrm{C}$ for four hours and weighed back afterwards. The resulting weight loss is proportional to the organic carbon $\left(\mathrm{C}_{\text {org }}\right)$.

The "Scheibler Gasometer" (Fa. Carl Hamm GmbH, Essen, Germany) determination of the total carbonate content is a volumetric method, relative to the dry mass of the sample. First, the sample must be pulverized and dried. Then a small part of the sample is sprinkled with $2 \mathrm{~mol} / \mathrm{l} \mathrm{HCl}$ in order to determine the sample quantity for the Gasometer based on the varying effervescence of the sample, which depends on the calcareous content. The sample was weighed $(0.3 \mathrm{~g}$ for very persistent effervescent samples to $5.0 \mathrm{~g}$ for non-sparkling samples) and filled into the gas development vessel, and the gas cylinders were filled with water up to the zero mark of the measuring cylinder using a pump. Next, $10 \mathrm{ml}$ of the hydrochloric acid was poured into the test tube in the gas evolution chamber and brought into contact with the sample. Due to the $\mathrm{CO}_{2}$ development, the water column of the measuring cylinder shifts. The carbonate content can be determined from the displaced water quantity. By comparison with pure calcium carbonate $\left(\mathrm{CaCO}_{3}\right)$ an equivalent content of $\mathrm{CaCO}_{3}$ of the $10-\mathrm{cm}$ bulk samples is determined.

The grain analyses were performed for every second sample of the 1000 samples, while the rest were archived for future analyses. The samples were weighed and allowed to react with $7.5 \% \mathrm{H}_{2} \mathrm{O}_{2}$ for three days to remove organic material. The clay aggregates were then crushed by ultrasonic waves, and the samples were sieved to $63-\mu \mathrm{m}$ grain size to retain the sand fraction. After sieving, the samples were dried again and weighed. Thin sections of the sieve samples were prepared. Then, a transparent two-component adhesive was applied to object slides, on which the grains were scattered in a single layer. The thin sections were then automatically scanned under polarized light with an Olympus BX51 microscope (Olympus K.K., Shinjuku Tokyo) and an Olympus SC50 camera on a Märzhäuser stage (Märzhäuser, Wetzlar).

Measurements were performed with the Stream motion software from Olympus. The different grains were visually separated, and one type of grain was identified as carbonate grains by using hydrochloric acid $(\mathrm{HCl})$. The grains were then automatically distinguished for each sample by their interference colors (Seelos and Sirocko, 2005; Dietrich and Seelos, 2010). These grain classifications were then exported as tables and imported into a RADIUS module, where the analysis was carried out. The RADIUS software package was originally introduced by Seelos and Sirocko (2005) and updated for this work (see Supplementary Material). It is a Matlab-based (The MathWork Corp., Natick) statistical application to calculate particle distribution and particle shape parameters of disturbed or undisturbed multi-compositional samples. In contrast to earlier versions of RADIUS, the new algorithm generates a set of parameters for every single particle (sorting, unconformity, skewness, kurtosis, mean grain size, formfactor, roundness, and content of the previously defined grain types from all analyzed grains; see Seelos and Sirocko, 2005; Seelos et al., 2009; Dietrich and Seelos, 2010), which allows the definition of selection criteria referring to the scientific question (see Supplementary Material for detailed information). The basic measuring data per particle are the equivalent circle diameter (ECD), the form factor $(\mathrm{FF})$, and the elongation (ELO).

The ECD is defined as:

$$
E C D=2 \sqrt{\frac{a}{\pi}}\left(a=\operatorname{area}\left(\mu m^{2}\right)\right)
$$


The FF is an attribute of surface roughness (range $0-1$ ), whereby 1 means totally plain and 0 means entirely rough surface:

$$
F F=4 \pi \frac{a}{P^{2}} \quad(P=\text { perimeter }(\mu m))
$$

The ELO is the quotient of the shortest vs. longest diameter (range $0-1$ ), whereby 1 means totally round and 0 means elongated:

$$
E L O=\frac{D_{\min }}{D_{\max }}(D=\text { diameter }(\mu m))
$$

The RADIUS results output several different parameters for each grain. The carbonate roundness turned out to be the most robust dust parameter for the present scientific question.

Figure 2 shows carbonate grains that differ in roundness. These are sorted from excellently rounded and eolian transported (see Fig. 2A) to well rounded and only slightly transported (Fig. 2B) to not rounded and almost not transported at all (see Fig. 2C). Figure 2D, in addition, shows carbonates, which are typical for in situ secondary carbonate growth. These are either completely unrounded and formed as a crust at the margins of the maar lake (see Fig. D2), or they are well rounded, indicating that they were formed at some distance and then transported (see Fig. D1).

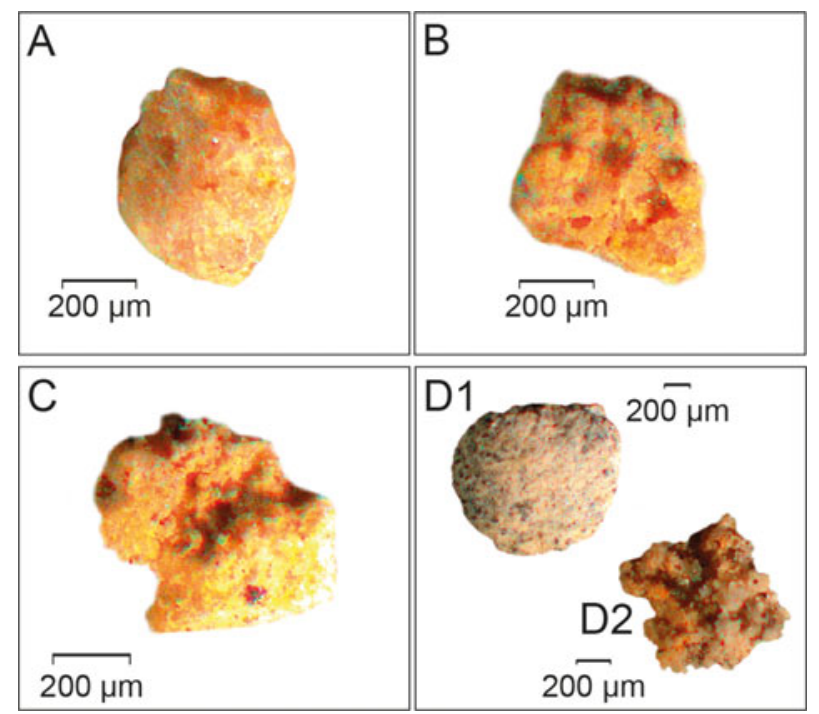

Figure 2. (color online) Exemplary carbonate grains found in the ELSA Dust Stack-20. (A) well-rounded, dull, eolian-transported carbonate grain, stack sample 671 (AU3 $68.6 \mathrm{~m}, ~ 39 \mathrm{ka}, \mathrm{GS} 9$ ); (B) slightly rounded with a short eolian transport carbonate grain, stack sample 485 (AU4 $49.7 \mathrm{~m}, \sim 30 \mathrm{ka}, \mathrm{GS} 5$ ); (C) unrounded with no transport carbonate grain, stack sample 647 (AU4 $66.1 \mathrm{~m}$, $\sim 37.5 \mathrm{ka}, \mathrm{GI} 8$ ); (D) carbonates from in-situ carbonate growth, either transported and rounded (D1, stack sample 787, AU3 80.3 m, 47.5 ka, GS13) or not (D2, stack sample 134, AU3 14.3 m, 14 ka, GI1).

\section{RESULTS}

Figures $3 \mathrm{~A}$ and $3 \mathrm{~B}$ show the stratigraphic correlation of the ELSA Dust Stack-20 LOI with almost all GI in the NGRIP ice core. Different stratigraphic nomenclature from the marine and terrestrial realms are also correlated (Vandenberghe, 1985; Lisiecki and Raymo, 2005; Sirocko et al., 2016). The MIS3 is named "Middle Pleniglacial" in terrestrial realms (60-29 ka; Vandenberghe 1985; see fig. 3 for stratigraphic correlation). The LGM (Clark et al., 2009; 26.5-19 ka) was partly synchronous with the "Late Pleniglacial," while the glacial termination was named "Late glacial" in terrestrial realms. The carbonate grain roundness of the ELSA Dust Stack-20 presents a terrestrial time series for the period of 60 to $\sim 13 \mathrm{ka}$ (see Fig. 3C) showing prominent increases within most GS; however, GS5.1 and GS4 are not visible. The sediments of GS12 show sedimentary disturbance, which Sirocko and colleagues (unpublished data) interpreted as having been caused by a complete freezing of the maar down to depths, disturbing the uppermost sediments of GS12 and GI12. The layering is disturbed; accordingly, the event did not preserve all information and the interpretation is difficult. Parts of GS12 were consequently removed from the data sets of carbonate grain roundness and $\mathrm{CaCO}_{3}$.

The carbonate roundness data are comparable to the GS of the NGRIP ice core (North Greenland Ice Core Project Members et al., 2004). In particular, the stadials that coincide with Heinrich events are identifiable. HE5a, HE5, HE4, and HE1 are visible in the carbonate roundness data, but HE3 and HE2 are not. The lowermost carbonate roundness values of the entire data set are found at the beginning of GI14 ( 53.5 ka). Subsequently, the roundness increases during GI14 and toward GS13/HE5, where the grain roundness values are very high. After the carbonate grain roundness values drop significantly at the end of HE5, they subsequently increase again in the trend toward HE4. However, this is not observed after HE4, where the carbonate grain roundness values vary between stadial/interstadial times, although the trend remains relatively homogeneous.

Figure 3D shows the $\mathrm{CaCO}_{3}$ time series indicating all stadials during the LGM. The first significant increase occurs simultaneously with the onset of HE3 ( 32 ka). Thereafter, the Heinrich stadials HE3, HE2, and HE1 are characterized by a significantly increased $\mathrm{CaCO}_{3}$ content. The characteristic dust double peak of the NGRIP ice core during HE2 (Fig. 4A; Ruth et al., 2007) can be recognized simultaneously (26 and $24 \mathrm{ka}$ ) in the $\mathrm{CaCO}_{3}$ values of the ELSA Dust Stack-20 (see Fig. 3D) as a two-stage increase. During the LGM the $\mathrm{CaCO}_{3}$ values vary consistently at relatively high levels. HE1, on the other hand, shows a further significant increase even at these high values.

Figure 3E displays the ELSA Dust Stack (2009) by Seelos et al. (2009). It shows basically all GI; only GI2 is hardly visible. HE5a, HE5, and HE3 are also visible. HE4 and HE2 can be guessed at, but HE1 is not apparent. While the GIs are identifiable, the GSs are not that easy to observe. 


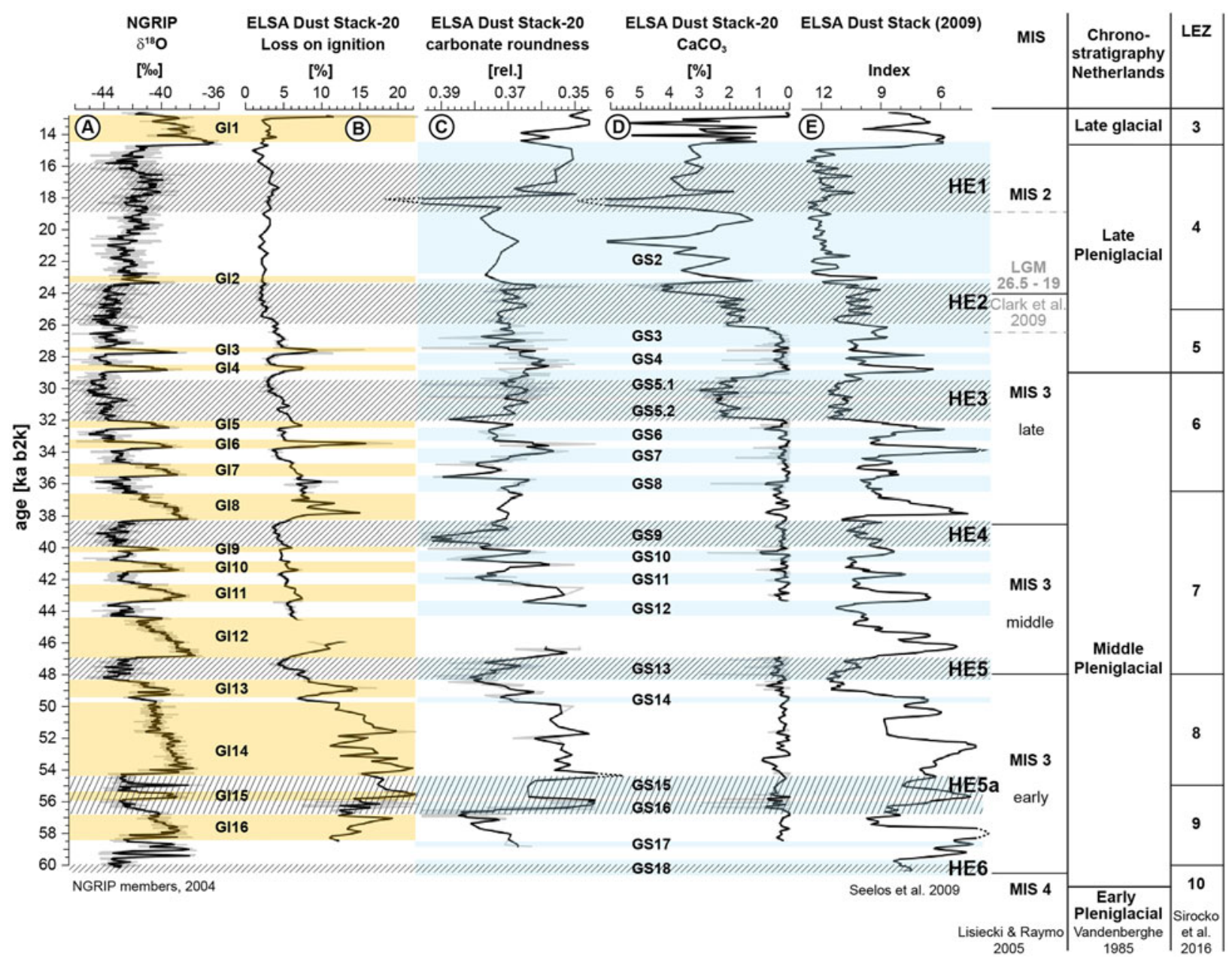

Figure 3. Comparison of climate proxies (B)-(E) for central Europe for $60-13 \mathrm{ka} \mathrm{b} 2 \mathrm{k}$ with the NorthGRIP $\delta^{18} \mathrm{O}$ climate record. All data were plotted in such a way that the spikes, which correlate to the Greenland Stadials (GS), can be found on the left side as in the well-known North Greenland Ice Core Project (NGRIP) diagram. (A). Light yellow bars indicate Greenland Interstadials (GI), light blue bars indicate GS, and shaded areas indicate Heinrich Events (Naafs et al., 2013; Rasmussen et al., 2014). (B) shows ELSA Dust Stack-20 loss on ignition data, which correspond to organic carbon documenting peaks during GI (Sirocko et al., unpublished data). (C) shows carbonate grain roundness (10 cm bulk samples [grey line: original data; black line: 200-year running mean-smoothed original data]) shows most GS by increased roundness values. HE1 shows the highest roundness values, even beyond the displayed scale, which is indicated by dots. (D) shows $\mathrm{CaCO}_{3}$ values of the ELSA Dust Stack-20 (10-cm bulk sample resolution). (E) shows the ELSA Dust Stack (2009) dust index (Seelos et al., 2009) with almost all GI visible. Landscape Evolution Zones (LEZ) for stratigraphic correlation can be found in Sirocko et al., 2016 (For interpretation of the references to color in this figure legend, the reader is referred to the web version of this article.)

The ELSA Dust Stack-20 carbonate roundness (see Fig. 4C) is compared to the global dust time series, which show the Heinrich events as a dominant parameter. The records are displayed with growing distance to the North Atlantic. Figure 4A shows the NGRIP ice core; Figures 4B, $4 \mathrm{D}$, and $4 \mathrm{E}$ represent marine archives; and Figures $4 \mathrm{C}$ and 4F show terrestrial records with defined Heinrich events.

Figure 4A shows the dust concentration of the NGRIP ice core (Ruth et al., 2007), which reveals all GSs by an increase in dust concentration. The largest dust concentrations of the last $60 \mathrm{ka}$ occur at the beginning of HE2 $(\sim 26 \mathrm{ka})$ and show a striking double peak. Figure 4B displays the dolomite/calcite ratio of the IODP-306-U1313 sediment core from the North Atlantic (Naafs et al., 2013). The ratio shows increased values during ice rafting debris deposition.
HE1, HE2, HE4, and HE5 can be observed within this data set, but HE3, HE5a, and HE6 are not represented like the other Heinrich events are.

Figure $4 \mathrm{C}$ shows the carbonate roundness introduced in Figure 3C. Most stadials, and especially the Heinrich events parallel to GSs, are strongly expressed. Figure 4D shows an eolian dust record off the coast of Senegal (Mulitza et al., 2008; Collins et al., 2013), where large amounts of Saharan dust were transported into the Atlantic. Particularly during the Heinrich events, large amounts of dust were deposited, and HE3 shows distinctly lower amounts than the other events. HE5a is not documented in this record.

The SO130-289KL sediment core (see Fig. 4E; Schulz, et al., 1998; Deplazes et al., 2013) shows reflectance data, which is an established proxy for changes in sediment 


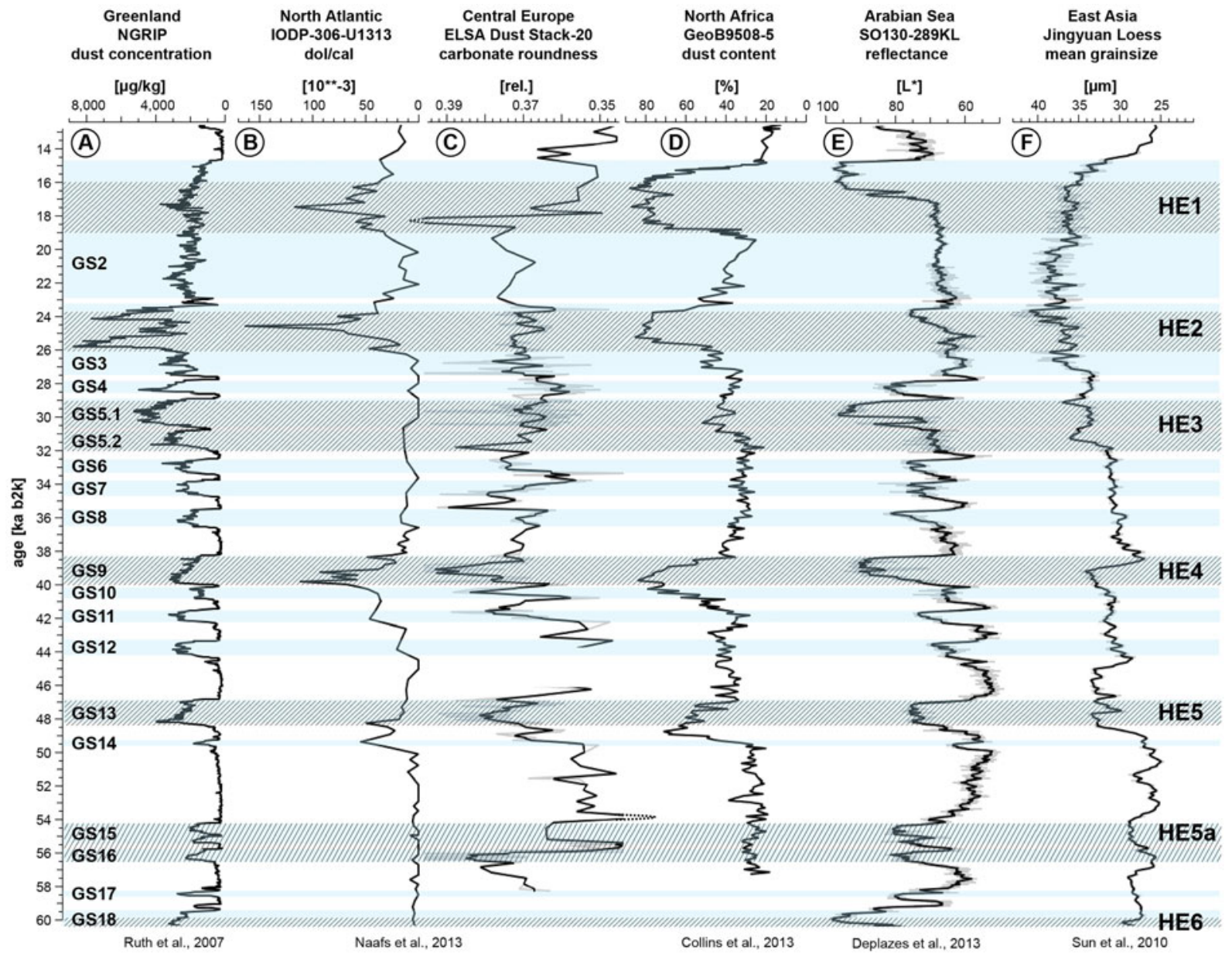

Figure 4. Comparison of dust-related timeseries from 60 to $13 \mathrm{ka} \mathrm{b2k}$ shown with growing distance from the North Atlantic. Light blue bars display Greenland stadials (GS) after Rasmussen and colleagues (2014); shaded areas show Heinrich events after Naafs and colleagues (2013) and Rasmussen and colleagues (2014). All data were plotted in such a way that the spikes, which correlate to the GS, can be found on the left side as in the well-known North Greenland Ice Core Project (NGRIP) diagram; (A) Greenland: NGRIP dust concentration; (B) North Atlantic: IODP-305-U1313 marine sediment core, dolomite/calcite ratio as ice raft debris proxy; (C) Central Europe: ELSA Dust Stack-20 terrestrial sediment core, carbonate grain roundness as regional dust proxy; (D) North Africa: GeoB9508-5 marine sediment core, dust content; (E) Arabian Sea: SO130-289KL marine sediment core, reflectance data; (F) East Asia: Jingyuan loess terrestrial archive, mean grainsize. All records show Heinrich events, regardless of the sediment archive type. (For interpretation of the references to color in this figure legend, the reader is referred to the web version of this article.)

composition, for the northeastern Arabian Sea. It shows not only the Heinrich events but also the GIs.

A record of the mean grain size of the Jingyuan Loess Plateau in East Asia shows loess stadial/interstadial variability (see Fig. 4F; Sun et al., 2010). An increasing deposition of coarse grains is observed during the stadials of the NGRIP ice core. Heinrich events tend to be even more coarse grained within the record.

\section{DISCUSSION}

The carbonate grains deflated from the north and southwest cannot reach the maar because of topographic barriers (see Fig. 1). The carbonates located $4 \mathrm{~km}$ to the east could not have entered the maar, because to do so they would have had to saltate a few meters uphill and through a river valley.
It is remarkable that two carbonate regions lay south of the maar, and both follow the Rhine strike direction (see Fig. 1). It can therefore be assumed that the two carbonate regions were connected during the Middle and Late Pleniglacial and are today covered by younger strata, probably glacial solifluction and Holocene colluvium. The area between the carbonates in the southwest and east of the map is higher than the Auel Maar, and thus saltating particles can easily reach the maar basin with winds from the southeast. Hence, we interpret this area (hatched in Fig. 1) as the region of origin of the carbonate grains, even though we could not find carbonate outcrops in the field today.

Well-rounded, dull eolian carbonate grains indicate stadials in the ELSA Dust Stack-20. The roundness shows increased values (0.39) during stadials compared to values during interstadials (0.37). Dust sedimentation was increased 
during the colder and drier intervals. These results match findings of previous studies, for example of Dietrich and Seelos (2010), Sirocko and colleagues (2013), and others. As all samples were sieved to $63 \mu \mathrm{m}$, no far-transported grains remain within the samples.Therefore, and in accordance with the results of Dietrich and Seelos (2010), carbonate grains were interpreted as having originated regionally. $\mathrm{CaCO}_{3}$ is interpreted to indicate easterly winds, not westerly, since no carbonate rocks can be found in the area directly west of the Auel Maar.

Between 60 and $32 \mathrm{ka}$ ( Middle Pleniglacial), $\mathrm{CaCO}_{3}$ values of the ELSA Dust Stack-20 range between 0\% and 1.5\% with higher values during the stadial phases. After the beginning of HE3 ( 32 ka) a general change in the transport system around the Auel Maar is visible. This can be explained by the increased appearance of easterly winds in central Europe during this time (Gullentops et al., 1981; Huijzer and Vandenberghe, 1998; Dietrich and Seelos, 2010). During Heinrich events, easterly wind activities were increased, especially during HE2 and HE1. In the Dehner Maar cores $(10 \mathrm{~km}$ west of Auel Maar), the content of dust within the sediments was about $75 \%$ between the beginning of HE3 and the end of HE2 (see Fig. 3E; Dietrich and Seelos, 2010). This corresponds to increased $\mathrm{CaCO}_{3}$ values during these time intervals within the ELSA Dust Stack-20. The main cause of these phenomena is assumed to be the significantly lower sea surface temperature in the North Atlantic with extended sea ice cover in addition to the increased size of the Laurentide Ice Sheet (Renssen et al., 2007). The postulated system change with HE3 in the sediments of Auel Maar can also explain why HE2, which is the Heinrich event with the highest dust content in the NGRIP data, is not as equally pronounced in the central European ELSA Dust Stack-20 sediments.

The HE5a, HE5, HE4, and HE1 are visible in the carbonate roundness data, while HE3, HE2, and HE1 are well developed in the $\mathrm{CaCO}_{3}$ data. ELSA Dust Stack (2009) and ELSA Dust Stack-20 are similar. While the 2009 Dust Stack mainly shows the GIs, the ELSA Dust Stack-20 mainly shows the GSs. The data of the ELSA Dust Stack-20 are from a single archive, the Auel Maar, while the 2009 Dust Stack contains cores from the Dehner Maar, Schalkenmehrener Maar, and Oberwinkler Maar from the last $60 \mathrm{ka}$. Therefore, stratigraphic inconsistencies are minimized in the ELSA Dust Stack-20 (see the Bayesian Age Model for the Auel cores; Sirocko et al., unpublished data).

Figure 4 shows that the Heinrich events were not limited to ice raft debris layers in the North Atlantic but had an impact on the continents as well. Climatic changes during the Heinrich events are found in marine and terrestrial sediments of the Northern Hemisphere and may also be seen globally (Muller et al., 2008).

\section{CONCLUSIONS}

We present a continuous terrestrial dust sediment record with most GSs and Heinrich events between 60 and 13 ka reconstructed from carbonate roundness of the ELSA Dust
Stack-20 and $\mathrm{CaCO}_{3}$ data for central Europe. The record allows five main conclusions to be drawn: (1) Carbonate grain roundness is a useful proxy to detect saltating eolian fraction for Auel dry maar sediments, because eoliantransported grains are rounded and frosted. (2) Carbonate grain roundness data document HE5a to HE4 and HE1; however, HE3 to HE1 become visible only in the carbonate percent record. (3) The discussion of the possible deflation areas of the carbonate sand fraction suggest wind directions from the south and southeast. These match the results of the ELSA Dust Stack (2009), which revealed easterly wind directions for the silt fraction. (4) The sand fraction documents strong wind speeds, which were apparently most severe during the Heinrich events. (5) The ELSA Dust Stack-20 data show that climate extremes during Heinrich events are not limited to the oceans, but also dominate the terrestrial climate between 60 and $13 \mathrm{ka}$.

\section{SUPPLEMENTARY MATERIAL}

The supplementary material for this article can be found at https:// doi.org/10.1017/qua.2020.81

\section{ACKNOWLEDGMENTS}

This work was supported by the Johannes Gutenberg University of Mainz and the Max-Planck Institute for Chemistry of Mainz. We strongly acknowledge Jef Vandenberghe, Dominik Faust, and an anonymous reviewer for the extensive and constructive reviews. We thank Johannes Albert and Sarah Britzius for discussions and help with the stratigraphic correlations; Philip Süßer, Jennifer Klose, Anastasia Zemlitskaya, Robert Deutsch, and Alexander Blum for sample preparation; Ignatius Perreira for the cartography work; and Petra Sigl for assistance with the figures.

\section{REFERENCES}

North Greenland Ice Core Project Members, Andersen, K.K., Azuma, N., Barnola, J.-M., Bigler, M., Biscaye, P., Caillon, N., Chappellaz, J., et al., 2004. High-resolution record of Northern Hemisphere climate extending into the last interglacial period. Nature 431, 147-151. https://doi.org/10.1038/nature02805.

Antoine, P., Catt, J., Lautridou, J.-P., Sommé, J., 2003. The loess and coversands of northern France and southern England. Journal of Quaternary Science 18, 309-318. https://doi.org/10.1002/ jqs. 750 .

Antoine, P., Rousseau, D.-D., Moine, O., Kunesch, S., Hatté, C., Lang, A., Tissoux, H., Zöller, L., 2009. Rapid and cyclic aeolian deposition during the Last Glacial in European loess: a highresolution record from Nussloch, Germany. Quaternary Science Reviews 28, 2955-2973. https://doi.org/10.1016/j.quascirev. 2009.08.001.

Antoine, P., Rousseau, D.-D., Zöller, L., Lang, A., Munaut, A.-V., Hatté, C., Fontugne, M., 2001. High-resolution record of the last Interglacial-glacial cycle in the Nussloch loess-palaeosol sequences, Upper Rhine Area, Germany. Quaternary International 76-77, 211-229. https://doi.org/10.1016/S1040-6182(00) 00104-X. 
Brauer, A., Endres, C., Negendank, J.F.W., 1999. Lateglacial calendar year chronology based on annually laminated sediments from Lake Meerfelder Maar, Germany. Quaternary International 61, 17-25. https://doi.org/10.1016/S1040-6182(99)00014-2.

Brunck, H., Sirocko, F., Albert, J., 2016. The ELSA-Flood-Stack: A reconstruction from the laminated sediments of Eifel maar structures during the last 60000 years. Global and Planetary Change 142, 136-146. https://doi.org/10.1016/j.gloplacha.2015. 12.003.

Clark, P.U., Dyke, A.S., Shakun, J.D., Carlson, A.E., Clark, J., Wohlfarth, B., Mitrovica, J.X., Hostetler, S.W., McCabe, A.M., 2009. The Last Glacial Maximum. Science 325, 710-714. https://doi.org/10.1126/science.1172873.

Collins, J.A., Govin, A., Mulitza, S., Heslop, D., Zabel, M., Hartmann, J., Röhl, U., Wefer, G., 2013. Abrupt shifts of the SaharaSahel boundary during Heinrich stadials. Climate of the Past 9, 1181-1191. https://doi.org/10.5194/cp-9-1181-2013.

Denton, G.H., Anderson, R.F., Toggweiler, J.R., Edwards, R.L., Schaefer, J.M., Putnam, A.E., 2010. The Last Glacial Termination. Science 328, 1652-1656. https://doi.org/10.1126/science. 1184119.

Deplazes, G., Lückge, A., Peterson, L.C., Timmermann, A., Hamann, Y., Hughen, K.A., Röhl, U., et al., 2013. Links between tropical rainfall and North Atlantic climate during the last glacial period. Nature Geoscience 6, 213-217. https://doi.org/10.1038/ ngeo1712.

Dietrich, S., Seelos, K., 2010. The reconstruction of easterly wind directions for the Eifel region (Central Europe) during the period 40.3-12.9 ka BP. Climate of the Past 6, 145-154. https://doi.org/ 10.5194/cp-6-145-2010.

Förster, M.W., Zemlitskaya, A., Otter, L.M., Buhre, S., Sirocko, F., 2020. Late Pleistocene Eifel eruptions: insights from clinopyroxene and glass geochemistry of tephra layers from Eifel Laminated Sediment Archive sediment cores. Journal of Quaternary Science 35, 186-198. https://doi.org/10.1002/jqs.3134.

Frechen, M., Ellwanger, D., Hinderer, M., Lämmermann-Barthel, J., Neeb, I., Techmer, A., 2010. Late Pleistocene fluvial dynamics in the Hochrhein Valley and in the Upper Rhine Graben: chronological frame. International Journal of Earth Science (Geol Rundsch) 99, 1955-1974. https://doi.org/10.1007/s00531-009-0482-9.

Frechen, M., Schirmer, W., 2011. Luminescence Chronology of the Schwalbenberg II Loess in the Middle Rhine Valley. E\&G Quaternary Science Journal 60, 78-89. https://doi.org/10.3285/ eg.60.1.05.

Godzik, J., 1991. Sedimentological record of eolian processes from the Upper Plenivistulian and the turn of Pleni- and Late Vistulian in Central Poland. Zeitschrift für Geomorphologie SupplementBand, 51-60.

Gullentops, F., Paulissen, E., Vandenberghe, J., 1981. Fossil periglacial phenomena in NE Belgium. Biuletyn Periglacjalny 28, 345-365.

Haesaerts, P., Borziac, I., Chekha, V.P., Chirica, V., Damblon, F., Drozdov, N.I., Orlova, L.A., Pirson, S., van der Plicht, J., 2009. Climatic Signature and Radiocarbon Chronology of Middle and Late Pleniglacial Loess from Eurasia: Comparison with the Marine and Greenland Records. Radiocarbon 51, 301-318. https://doi.org/10.1017/S0033822200033841.

Haesaerts, P., Damblon, F., Gerasimenko, N., Spagna, P., Pirson, S., 2016. The Late Pleistocene loess-palaeosol sequence of Middle Belgium. Quaternary International, Middle Palaeolithic in North-West Europe: Multidisciplinary Approaches 411, 25-43. https://doi.org/10.1016/j.quaint.2016.02.012.
Hatté, C., Fontugne, M., Rousseau, D.-D., Antoine, P., Zöller, L., Laborde, N.T., Bentaleb, I., 1998. $\delta^{13} \mathrm{C}$ variations of loess organic matter as a record of the vegetation response to climatic wchanges during the Weichselian. Geology 26, 583. https://doi.org/10.1130/ 0091-7613(1998)026<0583:CVOLOM>2.3.CO;2.

Huijzer, B., Vandenberghe, J., 1998. Climatic reconstruction of the Weichselian Pleniglacial in northwestern and Central Europe. Journal of Quaternary Science 13, 391-417. https://oi.org/10.1002/ (SICI)1099-1417(1998090)13:5<391::AID-JQS397>3.0.CO;2-6.

Kasse, C., 2002. Sandy aeolian deposits and environments and their relation to climate during the Last Glacial Maximum and Lateglacial in northwest and central Europe. Progress in Physical Geography: Earth and Environment 26, 507-532. https://doi.org/ 10.1191/0309133302pp350ra.

Krauß, L., Kappenberg, A., Zens, J., Kehl, M., Schulte, P., Zeeden, C., Eckmeier, E., Lehmkuhl, F., 2018. Reconstruction of Late Pleistocene paleoenvironments in southern Germany using two high-resolution loess-paleosol records. Palaeogeography, Palaeoclimatology, Palaeoecology, Eurasian Loess records: missing link to a better understanding of Northern hemisphere Pleistocene climate evolution 509, 58-76. https://doi.org/10.1016/j.palaeo. 2017.11.043.

Krinsley, D.H., Doornkamp, J.C., 2011. Atlas of Quartz Sand Surface Textures. Cambridge University Press.

Landesamt für Geologie und Bergbau, 2020. Geological Map of Rheinland-Pfalz. Public online Mapviewer: https://mapclient. lgb-rlp.de/?app=lgb\&view_id=4.

Lisiecki, L.E., Raymo, M.E., 2005. A Pliocene-Pleistocene stack of 57 globally distributed benthic $\delta{ }^{18} \mathrm{O}$ records: PliocenePleistocene Benthic Stack. Paleoceanography 20, PA1003. https://doi.org/10.1029/2004PA001071.

Lu, H., Wang, X., Ma, H., Tan, H., Vandenberghe, J., Miao, X., Li, Z., Sun, Y., An, Z., Cao, G., 2004. The Plateau Monsoon variation during the past $130 \mathrm{kyr}$ revealed by loess deposit at northeast Qinghai-Tibet (China). Global and Planetary Change, Human Dimensions and Natural Processes in Environmental Change 41, 207-214. https://doi.org/10.1016/j.gloplacha.2004.01.006.

Manikowska, B., 1985. On the fossil soils, stratigraphy and lithology of the dunes in Central Poland. Acta Geographica Lodziensia 52.

Meyer, W., 2013. Geologie der Eifel. 4th ed. Schweizerbart'sche, E., Stuttgart.

Mulitza, S., Prange, M., Stuut, J.-B., Zabel, M., Dobeneck, T. von, Itambi, A.C., Nizou, J., Schulz, M., Wefer, G., 2008. Sahel megadroughts triggered by glacial slowdowns of Atlantic meridional overturning. Paleoceanography 23 PA4206. https://doi.org/ 10.1029/2008PA001637.

Muller, J., Kylander, M., Wüst, R.A.J., Weiss, D., MartinezCortizas, A., LeGrande, A.N., Jennerjahn, T., Behling, H., Anderson, W.T., Jacobson, G., 2008. Possible evidence for wet Heinrich phases in tropical NE Australia: the Lynch's Crater deposit. Quaternary Science Reviews 27, 468-475. https://doi.org/ 10.1016/j.quascirev.2007.11.006.

Mycielska-Dowgiałło, E., Ludwikowska-Kędzia, M., 2011. Alternative interpretations of grain-size data from Quaternary deposits. Geologos 17, 189-203. https://doi.org/10.2478/v10118-011-0010-9.

Naafs, B.D.A., Hefter, J., Grützner, J., Stein, R., 2013. Warming of surface waters in the mid-latitude North Atlantic during Heinrich events: High SST during Heinrich Events. Paleoceanography 28, 153-163. https://doi.org/10.1029/2012PA002354.

Rasmussen, S.O., Bigler, M., Blockley, S.P., Blunier, T., Buchardt, S.L., Clausen, H.B., Cvijanovic, I., et al., 2014. A stratigraphic 
framework for abrupt climatic changes during the Last Glacial period based on three synchronized Greenland ice-core records: refining and extending the INTIMATE event stratigraphy. Quaternary Science Reviews, Dating, Synthesis, and Interpretation of Palaeoclimatic Records and Model-data Integration: Advances of the INTIMATE project(INTegration of Ice core, Marine and TErrestrial records, COST Action ES0907) 106, 14-28. https:// doi.org/10.1016/j.quascirev.2014.09.007.

Renssen, H., Kasse, C., Vandenberghe, J., Lorenz, S.J., 2007. Weichselian Late Pleniglacial surface winds over northwest and central Europe: a model-data comparison. Journal of Quaternary Science 22, 281-293. https://doi.org/10.1002/jqs.1038.

Rommens, T., Verstraeten, G., Peeters, I., Poesen, J., Govers, G., Van Rompaey, A., Mauz, B., Packman, S., Lang, A., 2007. Reconstruction of late-Holocene slope and dry valley sediment dynamics in a Belgian loess environment. The Holocene 17, 777-788. https://doi.org/10.1177/0959683607080519.

Rousseau, D.-D., Sima, A., Antoine, P., Hatté, C., Lang, A., Zöller, L., 2007. Link between European and North Atlantic abrupt climate changes over the last glaciation. Geophysical Research Letters 34. https://doi.org/10.1029/2007GL031716.

Ruth, U., Bigler, M., Röthlisberger, R., Siggaard-Andersen, M.-L., Kipfstuhl, S., Goto-Azuma, K., Hansson, M.E., Johnsen, S.J., Lu, H., Steffensen, J.P., 2007. Ice core evidence for a very tight link between North Atlantic and east Asian glacial climate. Geophysical Research Letters 34. https://doi.org/10.1029/ 2006 GL027876.

Schulz, H., von Rad, U., Erlenkeuser, H., von Rad, U., 1998. Correlation between Arabian Sea and Greenland climate oscillations of the past 110,000 years. Nature 393, 54-57. https://doi.org/ $10.1038 / 31750$.

Seelos, K., Sirocko, F., 2005. RADIUS-rapid particle analysis of digital images by ultra-high-resolution scanning of thin sections. Sedimentology 52, 669-681. https://doi.org/10.1111/j.13653091.2005.00715.x.

Seelos, K., Sirocko, F., Dietrich, S., 2009. A continuous highresolution dust record for the reconstruction of wind systems in central Europe (Eifel, Western Germany) over the past $133 \mathrm{ka}$. Geophysical Research Letters 36. https://doi.org/10.1029/ 2009GL039716.

Sirocko, F., Dietrich, S., Veres, D., Grootes, P.M., Schaber-Mohr, K., Seelos, K., Nadeau, M.-J., et al., 2013. Multi-proxy dating of Holocene maar lakes and Pleistocene dry maar sediments in the Eifel, Germany. Quaternary Science Reviews 62, 56-76. https://doi.org/10.1016/j.quascirev.2012.09.011.

Sirocko, F., Knapp, H., Dreher, F., Förster, M.W., Albert, J., Brunck, H., Veres, D., et al., 2016. The ELSA-Vegetation-Stack: Reconstruction of Landscape Evolution Zones (LEZ) from laminated Eifel maar sediments of the last 60,000 years. Global and
Planetary Change 142, 108-135. https://doi.org/10.1016/j.gloplacha.2016.03.005.

Sprafke, T., Obreht, I., 2016. Loess: Rock, sediment or soil-What is missing for its definition? Quaternary International, Kukla Loessfest 399, 198-207. https://doi.org/10.1016/j.quaint.2015. 03.033

Sun, Y., Wang, X., Liu, Q., Clemens, S.C., 2010. Impacts of postdepositional processes on rapid monsoon signals recorded by the last glacial loess deposits of northern China. Earth and Planetary Science Letters 289, 171-179. https://doi.org/10.1016/j.epsl. 2009.10.038.

van Huissteden, K. (J), Gibbard, P.L., Briant, R.M., 2001a. Periglacial fluvial systems in northwest Europe during marine isotope stages 4 and 3. Quaternary International 79, 75-88. https:// doi.org/10.1016/S1040-6182(00)00124-5.

van Huissteden, K. (J), Schwan, J.C.G., Bateman, M.D., 2001 b. Environmental conditions and paleowind directions at the end of the Weichselian Late Pleniglacial recorded in aeolian sediments and geomorphology (Twente, Eastern Netherlands). Netherlands Journal of Geosciences 80, 1-18. https://doi.org/10.1017/ S0016774600022277.

Vandenberghe, J., 1985. Paleoenvironment and stratigraphy during the last glacial in the Belgian-Dutch border region. Quaternary Research 24, 23-38. https://doi.org/10.1016/0033-5894(85)90081-X.

Vandenberghe, J., 1991. Changing conditions of aeolian sand deposits during the last deglaciation period. Zeitschrift für Geomorphologie N.F. 90, 193-207.

Vandenberghe, J., 2013. Grain size of fine-grained windblown sediment: A powerful proxy for process identification. EarthScience Reviews 121, 18-30. https://doi.org/10.1016/j.earscirev. 2013.03.001.

Vandenberghe, J., Huijzer, B.S., Mücher, H., Laan, W., 1998. Short climatic oscillations in a western European loess sequence (Kesselt, Belgium). Journal of Quaternary Science 13, 471-485. https://doi.org/10.1002/(SICI)1099-1417(1998090)13:5<471::AIDJQS401>3.0.CO;2-T.

Weber, M., Scholz, D., Schroeder-Ritzrau, A., Deininger, M., Spoetl, C., Lugli, F., Mertz-Kraus, R., et al., 2018. Evidence of warm and humid interstadials in central Europe during early MIS 3 revealed by a multi-proxy speleothem record. Quaternary Science Reviews 200, 276-286. https://doi.org/10.1016/j.quascirev. 2018.09.045.

Wernli, H., Pfahl, S., 2009. Grundlage des Klimas und extremer Wettersituationen, in: Wetter, Klima (Ed.), Menschheitsentwicklung. Von der Eiszeit bis ins 21. Jahrhundert. Theiss, Stuttgart, pp. 44-52.

Woronko, B., Pisarska-Jamroży, M., 2016. Micro-Scale Frost Weathering of Sand-Sized Quartz Grains. Permafrost and Periglacial Processes 27, 109-122. https://doi.org/10.1002/ppp.1855. 